\title{
Розвиток виробництва безпілотних роботизованих систем в Україні засобами міжнародного воєнно-економічного співробітництва
}

\author{
Поліна Толок * 1 А \\ А Центральний науково-дослідний інститут озброєння та військової техніки Збройних Сил України, м. Київ, Україна
}

Received: September 4, 2021 | Revised: October 16, 2021 | Accepted: October 30, 2021

JEL Classification: F15, L32, O19.

DOI: $10.33445 /$ sds.2021.11.5.5

\begin{abstract}
Анотація
У статті проаналізовано міжнародний досвід розробки та виробництва безпілотних роботизованих систем, як перспективний напрям розвитку озброєнь та військової техніки. Висвітлено нормативно-правові, організаційні та економічні чинники, які стримують їх розвиток в України. Визначено пріоритети розвитку безпілотних роботизованих систем, одним із яких $€$ застосування для цього інструментів міжнародного воєнно-економічного співробітництва, під яким запропоновано вважати міцні і тривалі зв'язки кооперативного характеру, в основі яких лежать вироблені та узгоджені наперед наміри, що закріплені в довготривалих економічних угодах і договорах у сфері розроблення та виробництва БПЛА та БПНА між вітчизняними компаніями - розробниками безпілотних роботизованих систем та провідними закордонними компаніями США, Туреччини, інших держав - членів НАТО, Ізраїлю з питань реалізації спільних проектів у цій сфері. Запропоновано для активізації виробництва безпілотних роботизованих систем різного призначення застосувати державно-приватне партнерство у оборонно-промисловому секторі України, що надає можливість створення спільних підприємств у формі господарських організацій для реалізації інвестиційно-інноваційних, капіталомістких, довготривалих проектів, що $€$ міжнародною практикою. Саме завдяки цьому виникає можливість розподіляти ризики проекту, залучати до нього значні інвестиції та просувати товари/послуги на ринки інших країн. Запропоновано заходи з розвитку державно-приватного партнерства у цій сфері, зокрема: впровадження економічних механізмів ефективної взаємодії наукових установ та виробничих комплексів різних форм власності, а також державно-приватного партнерства підприємств, які забезпечують розроблення, виготовлення і модернізацію безпілотної техніки. Зазначено пріоритет розвитку міжнародного воєнно-економічного співробітництва у сфері безпілотної техніки: посилення експортного потенціалу вітчизняного ОПК, що має здійснюватися шляхом: розроблення та прийняття нормативноправових актів, спрямованих на забезпечення заходів міжнародного воєнно-економічного співробітництва і реалізацію офсетних угод під час закупівлі роботизованих платформ та робототехніки за імпортом; укладення міжурядових угод з міжнародного воєнноекономічного співробітництва, що передбачають взаємний захист інвестицій, технологій, конкретні заходи із спільного виробництва безпілотної техніки для потреб ринків третіх держав; створення сприятливих умов для реалізації міжнародних проектів у сфері озброєнь і військової техніки, зокрема, забезпечення умов для створення спільного виробництва зразків безпілотної техніки, які не виготовляються в Україні.
\end{abstract}

Ключові слова: міжнародне воєнно-економічне співробітництво, безпілотні роботизовані системи, державно-приватне партнерство.

\footnotetext{
1 * Corresponding author: кандидат економічних наук, старший науковий співробітник, e-mail: tolok100@meta.ua, ORCID: 0000-0002-2481-8152
} 


\section{Постановка проблеми}

Розробка та виробництво безпілотних роботизованих систем переживає швидке зростання в світі. Аналіз сучасних тенденцій розвитку армій провідних країн світу свідчить про акценти у розробках на створення безпілотних роботизованих систем (платформ) різного виду базування (повітряного, наземного та морського).

Експерти безпілотної техніки прогнозують, що провідні країни світу матимуть до 2025 р. у складі бойової авіації до 80\% безпілотної складової. За даними дослідницької компанії “Тил Груп" (Teal Group) в 2026 році в світі буде вироблено військових безпілотників на 10,3 млрд дол. США (для порівняння, в 2017 році було вироблено військових дронів на 4,2 млрд дол.). Business Insider Intelligence прогнозує, що сукупний продаж БПЛА у 2021 р. перевищить 12 млрд. дол. США [1].

В Україні станом на 2020 р. виробництво безпілотних роботизованих систем тільки розпочалося. У Стратегії національної безпеки України, затвердженій Указом Президента України від 14 вересня 2020 р. № 392, зазначається, що використання робототехніки та автономних безпілотних апаратів $\epsilon$ одним із сучасних напрямів розроблення систем озброєнь [2]. Крім того, у Стратегії розвитку оборонно-промислового комплексу України, затвердженій Указом Президента України від 20.08.2021 р. № 372/2021, передбачено створення безекіпажних платформ і ударної робототехніки, оснащення "солдата майбутнього" тощо [3]. Одним з варіантів вирішення цієї проблеми для України $\epsilon$ розроблення власних зразків, модернізація вітчизняних розробок безпілотних апаратів, 3 урахуванням того, що Україна не володіє повним циклом створення подібної техніки, то розробити зразки такого озброєння самостійно неможливо в короткі терміни. Іншим варіантом вирішення цієї актуальної проблеми $€$ використання перспективних розробок безпілотних апаратів необхідних параметрів провідних держав у цій сфері США, Ізраїлю, Туреччини засобами міжнародного воєнно-економічного співробітництва (MBEC) [1]. Ураховуючи можливості залучення компетенцій, кадрів, інновацій, технологій, капіталу і досвіду управління приватних підприємств і організацій шляхом застосування механізмів державно-приватного партнерства в оборонно-промисловому комплексі для спільного вирішення задач забезпечення національної безпеки, підвищення ефективності використання коштів державного бюджету і активів підприємств, установ і організацій в обороннопромисловому комплексі, спільного розроблення та реалізації інвестиційних та інноваційних проектів, вдосконалення управління та інформаційно-аналітичного забезпечення у сфері обороннопромислового комплексу, налагодження трансферу технологій [3], потребують дослідження проблема розробки та виробництва роботизованих систем в межах міжнародного воєнно-економічного співробітництва.

\section{Аналіз останніх досліджень та публікацій}

Розв'язання даної проблеми Демідова, С. Згурця, І.Іванової, В.Тютюнника, започатковано у роботах В. Горбуліна, В. М. Шевцова, В. Шеховцова, Ю. Шимова та ін. Бадрака, О. Велічка, В. Горовенка, Б. [4-8].

\section{Постановка завдання}

Мета статті полягає у визначенні шляхів реформування та розвитку виробництва безпілотних роботизованих систем на підприємствах оборонної галузі України 
шляхом розвитку міжнародного воєнноекономічного співробітництва (MBEC) 3 використанням

партнерства. державно-приватного

\section{Виклад основного матеріалу}

Ключовими проблемними аспектами розвитку оборонно-промислового комплексу, що гальмують розвиток безпілотних роботизованих систем в Україні $\epsilon$ :

недосконалість системи визначення потреб в озброєнні, військовій і спеціальній техніці та формування планів закупівель безпілотної техніки на найближчу перспективу для сил сектору безпеки і оборони, відсутність максимально можливої публічності процесу формування державного оборонного замовлення та відбору виконавців;

відсутність дієвих державних програм переходу від виробництва одиночних та малосерійних виробів до серійного виробництва новітніх зразків безпілотної техніки;

слабка концентрація фінансових та інших ресурсів для реалізації пріоритетних напрямів переходу на створення безпілотної техніки нових поколінь;

повна відсутність державної підтримки та фінансування розвитку безпілотних технологій у сфері оборонно-промислового комплексу України, проведення фундаментальних досліджень в інтересах оборонно-промислового комплексу, стимулювання нових науково-технічних напрямів;

відсутність чіткої державної політики стимулювання інноваційного розвитку безпілотної техніки у межах обороннопромислового комплексу, підтримки лізингових та офсетних угод;

відсутність гнучкої політики ціноутворення на продукцію військового призначення, зокрема, безпілотної техніки;

недооцінка впливу експортного потенціалу підприємств - виробників безпілотної техніки на їх фінансовоекономічний стан та відсутність державної підтримки зазначених підприємств, продукція яких має значний експортний потенціал;

відсутність доступних кредитів для підприємств - виробників безпілотної техніки [3].

Низький рівень міжнародного воєнноекономічного співробітництва 3 метою залучення міжнародних компаній до інвестування у підприємства обороннопромислового комплексу у напрямі виробництва безпілотних роботизованих систем в Україні обумовлений:

відсутністю нормативно-правових актів щодо удосконалення засад державної політики у сфері міжнародного воєнноекономічного співробітництва, зокрема, Стратегії міжнародного воєнно-економічного співробітництва України 3 іноземними державами;

браком нормативно-правової бази щодо участі підприємств оборонно-промислового комплексу у міжнародному співробітництві;

низьким рівнем впровадження механізмів державного протекціонізму та державної підтримки експортного потенціалу, розширення експортних можливостей підприємств оборонної промисловості всіх форм власності;

відсутністю механізмів державного регулювання у сфері трансферу технологій, державної підтримки виконання проектів і програм у рамках міждержавних угод та державних гарантій виконання зовнішньоекономічних контрактів у сфері міжнародного воєнно-економічного співробітництва;

недостатньо активним використанням механізму виставкової діяльності з метою просування продукції військового i цивільного призначення та подвійного використання на зовнішні ринки та залучення перспективних технологій в Україну;

відсутністю привабливих умов для 
залучення іноземних інвестицій в оновлення технологічної бази підприємств, зокрема шляхом трансферу в Україну сучасних технологій, залучення науково-технічного потенціалу до реалізації спільних високотехнологічних проектів як в Україні, так і за кордоном [3].

3 огляду на зазначене, необхідно визначити розроблення та виробництво безпілотної техніки одним з пріоритетних напрямів розвитку оборонно-промислового комплексу України. Потребує активізації міжнародне воєнно-економічне співробітництво - міцні і тривалі зв'язки кооперативного характеру, в основі яких лежать вироблені та узгоджені наперед наміри, що закріплені в довготривалих економічних угодах i договорах у сфері розроблення та виробництва безпілотної техніки між вітчизняними та провідними закордонними компаніями - розробниками безпілотних роботизованих систем, а також створення вітчизняних установ із сертифікації безпілотної техніки на відповідність світовим стандартам якості.

Важливим пріоритетом розвитку міжнародного воєнно-економічного співробітництва у сфері безпілотної техніки $\epsilon$ посилення експортного потенціалу вітчизняного ОПК, що має здійснюватися шляхом:

розроблення та прийняття нормативноправових актів, спрямованих на забезпечення заходів міжнародного воєнно-економічного співробітництва і реалізацію офсетних угод під час закупівлі роботизованих платформ та робототехніки за імпортом;

укладення міжурядових угод з міжнародного воєнно-економічного співробітництва, що передбачають взаємний захист інвестицій, технологій, конкретні заходи із спільного виробництва безпілотної техніки для потреб ринків третіх держав;

створення сприятливих умов для реалізації міжнародних проектів у сфері озброєнь і військової техніки, зокрема, забезпечення умов для створення спільного виробництва зразків безпілотної техніки, які не виготовляються в Україні [3].

Необхідно врахувати також завдання та заходи 3 розвитку державно-приватного партнерства у цій сфері, зокрема: впровадження економічних механізмів ефективної взаємодії наукових установ та виробничих комплексів різних форм власності, а також державно-приватного партнерства підприємств, які забезпечують розроблення, виготовлення і модернізацію безпілотної техніки.

У розвинених країнах світу застосування ДПп у забезпеченні національної безпеки $\epsilon$ поширеною практикою. В Європейському Союзі розвитку взаємодії державного та приватного сектору приділяється значна увага. Зокрема, в офіційних документах Європейської Комісії вказується на необхідність реалізації механізмів ДПп на загальноєвропейському рівні, що передбачає визначення пріоритетних напрямів державної політики, цільових завдань i критеріїв оцінки їх виконання в галузі безпеки, а також визначення та розповсюдження інноваційних підходів до гарантування безпеки. До того ж наголошується, що у сфері реалізації політики безпеки ДПп забезпечує стійкість критичної інфраструктури в інтересах посилення національної безпеки у цілому. Передовими країнами у формуванні та розвитку ДПП вважають Велику Британію, Францію, Німеччину та США. У цих країнах створення правової основи та інституційне забезпечення $\epsilon$ першоосновою формування ефективної моделі державно-приватного партнерства у сфері безпеки.

У Стратегії розвитку обороннопромислового комплексу України, затвердженій Указом Президента України від 20 серпня 2021 року № 372/2021 закріплено необхідність забезпечення доступу суб'єктів господарювання всіх форм власності до участі у проектах зі створення та виробництва оборонної продукції, впровадження і реалізація державно-приватного партнерства, сприяння залученню інвестицій на 
внутрішньому та зовнішньому ринках, сприяння розвитку підприємництва та подальшому сталому функціонуванню приватного сектору; зняття заборони на створення спільних підприємств та провадження спільної діяльності, залучення іноземного капіталу в розвиток виробничих потужностей українських підприємств, удосконалення системи державноприватного партнерства.

Серед головних пріоритетів визначено забезпечення розвитку обороннопромислового комплексу шляхом широкої інтеграції з високотехнологічним цивільним сектором промисловості.

Важливою умовою розвитку ОПК передбачено забезпечення інноваційної діяльності у сфері оборонно-промислового комплексу, в т.ч. шляхом:

забезпечення стимулювання приватної підприємницької ініціативи у виконанні завдань розвитку оборонно-промислового комплексу;

створення на базі підприємств обороннопромислового комплексу державної та приватної форми власності об'єднань (із залученням наукових організацій, підприємств, вищих навчальних закладів і фінансових установ) для впровадження у виробництво високих технологій, комерціалізації науково-технічних розробок, виконання програм розвитку регіонів та програм реструктуризації підприємств оборонно-промислового комплексу;

створення учасниками різних форм власності індустріальних та технологічних парків у сфері високих технологій для забезпечення запуску, виведення на ринок $\mathrm{i}$ виробництва високотехнологічної продукції, послуг і технологій в інтересах оборони і безпеки держави, зокрема, шляхом інтеграції з науковими і (або) освітніми організаціям;

залучення компетенцій, кадрів, інновацій, технологій, капіталу і досвіду управління приватних підприємств і організацій шляхом застосування механізмів державноприватного партнерства В обороннопромисловому комплексі для спільного вирішення задач забезпечення національної безпеки, підвищення ефективності використання коштів державного бюджету і активів підприємств, установ і організацій в оборонно-промисловому комплексі, спільного розроблення та реалізації інвестиційних та інноваційних проектів, вдосконалення управління та інформаційноаналітичного забезпечення у сфері обороннопромислового комплексу, налагодження трансферу технологій;

впровадження економічних механізмів ефективної взаємодії наукових установ та виробничих комплексів різних форм власності, державно-приватного партнерства підприємств, які забезпечують розроблення, виготовлення, модернізацію і ремонт продукції військового призначення та подвійного використання.

3 метою унормування взаємодії державного та приватного секторів оборонної промисловості України необхідно прийняти низку законодавчих актів, передусім, Закон “Про розробку та виробництва озброєння та військової техніки".

Прийнятий Закон України “Про особливості реформування підприємств оборонно-промислового комплексу державної форми власності" (1630-ІХ від 13.07.2021 р., набуття чинності 06.10.2021р.) надає можливість створення спільних підприємств у формі господарських організацій для реалізації інвестиційноінноваційних, капіталомістких, довготривалих проектів, що $€$ міжнародною практикою. Саме завдяки цьому виникає можливість розподіляти ризики проекту, залучати до нього значні інвестиції та просувати товари/послуги на ринки інших країн.

\section{Висновки}

\begin{tabular}{ccrlrl} 
Розвиток & міжнародного & воєнно- & застосуванням & \multicolumn{2}{c}{ державно-приватного } \\
економічного & співробітництва & із партнерства & у & секторі о оборонно-
\end{tabular}


промислового комплексу України сприятиме лібералізації зовнішньоекономічної діяльності товарами та послугами військового призначення та подвійного використання для суб'єктів оборонної галузі усіх форм власності, зокрема, забезпечать нову хвилю розвитку безпілотних роботизованих систем в Україні.

\section{Список використаних джерел}

1. Шершаков О.М., Шемаєв В.М., Бегма В.М. щодо розвитку виробництва безпілотних роботизованих систем на основі державно-приватного партнерства. Аналітична записка / О. М. Шершаков, В. M. ШемаєB, В. M. Бегма. URL: https://niss.gov.ua/sites/default/files/202012/az-15.12.20.pdf

2. Стратегія національної безпеки України, затверджена Указом Президента України від 14 вересня 2020 р. № 392. URL: https://zakon.rada.gov.ua.

3. Стратегія розвитку обороннопромислового комплексу України, затверджена Указом Президента України від 20 серпня 2021 р. № 372/2021. URL: https://www.president.gov.ua/documents/3 722021-39733

4. Горбулін В. П. Входження ОПК України в європейський оборонно-промисловий простір / В.П. Горбулін, В.С. Шеховцов, А.І. Шевцов // Стратегічні пріоритети. - 2015. №1(34). - С. 5-10.

5. Бадрак В. Особливості реформування збройних сил та оборонно-промислових комплексів країн Центральної та східної Європи: аналітичне дослідження / В.В. Бадрак, С.Ю. Гончаров, А.В. Міхненко; під заг. ред. Бадрака В.В. - К.: ЦІАКР, 2014. 192 c.

6. Величко О. Ф., Демідов Б. О., Науменко М. В. Методичний підхід до обґрунтування доцільності модернізації зразків озброєння і військової техніки в рамках військово-технічного співробітництва 3 іноземними державами / О. Ф. Величко, Б. О. Демідов, М. В. Науменко.// Системи озброєння і військова техніка, 2008. - № 2. - C. 26-29.

7. Бегма В. М. Перспективи України щодо експорту технологій виробництва товарів військового призначення та подвійного використання як інноваційного напряму розвитку вітчизняної економіки / В. М. Бегма, Б. П. Щеглюк // Проблеми науки. 2013. - №. 12. - С. 21-27.

8. Шимов Ю. Ю. Державно-приватне партнерство В оборонно-промисловій сфері України/Ю.Ю. Шимов // Стратегічні пріоритети, № 2 (35), 2015 р. С. 20-25.

\section{Развитие производства беспилотных роботизированных систем в Украине посредством международного военно- экономического сотрудничества}

\footnotetext{
Полина Толок * 1 А

* Corresponding author: ${ }^{1}$ кандидат экономических наук, старший научный сотрудник, e-mail: tolok100@meta.ua, ORCID: 0000-0002-2481-8152

А Центральный научно-исследовательский институт вооружения и военной техники Вооружённых Сил Украины, г. Киев, Украина
}

\section{Аннотация}

В статье проанализировано международный опыт разработки и производства беспилотных роботизированных систем, как перспективное направление развития вооружений и военной техники. Освещены нормативно-правовые, организационные и экономические факторы, которые сдерживают их развитие в Украине. Определены приоритеты развития беспилотных роботизированных систем, одним из которых является применение для этого инструментов международного военно-экономического сотрудничества, под которым предложено считать прочные и длительные связи 
кооперативного характера, в основе которых лежат произведенные и согласованные заранее намерения, которые закреплены в долгосрочных экономических соглашениях и договорах в сфере разработки и производства БПЛА и БПНА между отечественными компаниями-разработчиками беспилотных роботизированных систем и ведущими зарубежными компаниями США, Турции, других государств-членов НАТО, Израиля по вопросам реализации совместных проектов в этой сфере. Предложено объединение усилий государственного и частного секторов оборонно-промышленного комплекса Украины для активизации производства беспилотных роботизированных систем различного назначения, что дает возможность создания совместных предприятий в форме хозяйственных организаций для реализации инвестиционно-инновационных, капиталоемких, долгосрочных проектов и является международной практикой. Именно благодаря этому появляется возможность распределять риски проекта, привлекать к нему значительные инвестиции и продвигать товары / услуги на рынки других стран. Предложены меры по развитию государственно-частного партнерства в этой сфере, в частности: внедрение экономических механизмов эффективного взаимодействия научных и производственных комплексов различных форм собственности, а также государственночастного партнерства предприятий, обеспечивающих разработку, изготовление и модернизацию беспилотной техники. Указано приоритет развития международного военно-экономического сотрудничества в сфере беспилотной техники: усиление экспортного потенциала отечественного ОПК, которое должно осуществляться путем: разработки и принятия нормативно-правовых актов, направленных на обеспечение мероприятий международного военно-экономического сотрудничества и реализацию офсетных сделок при закупке роботизированных платформ и робототехники по импорту; заключения межправительственных соглашений по международному военноэкономическому сотрудничеству, предусматривающие взаимную защиту инвестиций, технологий, конкретные меры по совместному производству беспилотной техники для нужд рынков третьих стран; создание благоприятных условий для реализации международных проектов в сфере вооружений и военной техники, в частности, обеспечение условий для создания совместного производства образцов беспилотной техники, которые не производятся в Украине.

Ключевые слова: международное военно-экономическое сотрудничество, беспилотные роботизированные системы, государственно-частное партнерство.

\title{
Development of the production of unmanned robotic systems in Ukraine through international military-economic cooperation
}

\author{
Polina Tolok * 1 A \\ * Corresponding author: ${ }^{1} \mathrm{PhD}$ in Economics, Researcher, e-mail: tolok100@meta.ua, ORCID: 0000-0002-2481-8152 \\ ${ }^{A}$ Central Research Institute of Armaments and Military Equipment Military of Defece of Ukraine, Kyiv, Ukraine
}

\begin{abstract}
The article analyzes the international experience in the development and production of unmanned robotic systems as a promising area for the development of weapons and military equipment. The problem is the need for scientific substantiation of a number of unresolved issues related to achieving a balance between ensuring the required level of economic and financial security of the country and the ability to ensure its economic stability and development of its economic potential. The purpose of the article is to substantiate the ways of reforming and developing the production of unmanned robotic systems at the enterprises of the defense industry of Ukraine through the development of international military-economic cooperation using public-private partnership. The normative-legal, organizational and economic factors that
\end{abstract}


hinder their development in Ukraine are covered. One of the options for solving this problem for Ukraine is to develop its own models, modernize domestic developments of unmanned aerial vehicles, given that Ukraine does not have a full cycle of such equipment, it is impossible to develop samples of such weapons in the short term. Another option to solve this urgent problem is to use promising developments of unmanned aerial vehicles of the necessary parameters of the leading states in this field - the United States, Israel, Turkey by means of international military-economic cooperation (IVEC).

Priorities for the development of unmanned robotic systems have been identified, one of which is the use of international military-economic cooperation instruments, which are proposed to include strong and lasting cooperative ties, based on preconceived and agreed intentions, which are enshrined in long-term economic agreements and treaties. in the development and production of UAVs and UAVs between domestic companies - developers of unmanned robotic systems and leading foreign companies in the United States, Turkey, other NATO member states, Israel on the implementation of joint projects in this area. It is proposed to unite the efforts of the public and private sectors of the defense-industrial complex of Ukraine to intensify the production of unmanned robotic systems for various purposes, which makes it possible to create joint ventures in the form of economic organizations for the implementation of investment and innovation, capital-intensive, long-term projects and is an international practice. It is thanks to this that it becomes possible to distribute the risks of the project, attract significant investments to it and promote goods / services to the markets of other countries. Measures are proposed for the development of public-private partnerships in this area, in particular: the introduction of economic mechanisms for effective interaction between scientific and industrial complexes of various forms of ownership, as well as public-private partnerships of enterprises that ensure the development, manufacture and modernization of unmanned vehicles. The priority of the development of international military-economic cooperation in the field of unmanned vehicles is indicated: strengthening the export potential of the domestic defense industry, which should be carried out through: the development and adoption of regulatory legal acts aimed at ensuring international military-economic cooperation and the implementation of offset transactions in the purchase of robotic platforms and import robotics; the conclusion of intergovernmental agreements on international military-economic cooperation, providing for the mutual protection of investments, technologies, specific measures for the joint production of unmanned vehicles for the needs of the markets of third countries; creating favorable conditions for the implementation of international projects in the field of weapons and military equipment, in particular, providing conditions for the creation of joint production of unmanned vehicles that are not produced in Ukraine.

Keywords: international military-economic cooperation, unmanned robotic systems, publicprivate partnership.

\section{References}

1. Shershakov O. M., Shemayev V. M., Behma V. M. Shchodo rozvytku vyrobnytstva bezpilotnykh robotyzovanykh system na osnovi derzhavno-pryvatnoho partnerstva. [Regarding the development of production of unmanned robotic systems on the basis of public-private partnership]. Analitychna zapyska. Available from: https://niss.gov.ua/sites/default/files/202012/az-15.12.20.pdf
2. Stratehya natsionalnoyi bezpeky Ukrayiny, zatverdzhena Ukazom Prezydenta Ukrayiny vid 14 veresnya 2020 r. № 392. [National Security Strategy of Ukraine, approved by the Decree of the President of Ukraine of September 14, 2020 № 392] Available from: https://zakon.rada.gov.ua.

3. Stratehiya rozvytku oboronno-promyslovoho kompleksu Ukrayiny, zatverdzhena Ukazom Prezydenta Ukrayiny vid 20 serpnya $2021 \mathrm{r}$. № 372/2021. [Strategy for the development 
of the defense-industrial complex of [Methodical approach to substantiation of Ukraine]. Available from: expediency of modernization of samples of https://www.president.gov.ua/documents/3 armaments and military equipment in the 722021-39733.

4. Horbulin V.P., Shekhovtsov V.S., Shevtsov A.I. (2015). Vkhodzhennia OPK Ukrainy v yevropeiskyi oboronno-promyslovyi prostir [The entry of Ukraine's defense industry into the European defense-industrial space], Stratehichni priorytety, no 1(34), PP. 5-10.

5. Badrak V. (2014) Osoblyvosti reformuvannia zbroinykh syl ta oboronno-promyslovykh kompleksiv krain Tsentralnoi ta skhidnoi Yevropy: analitychne doslidzhennia [Features of Reforming the Armed Forces and Defense Industries of Central and Eastern Europe: An Analytical Study]. Kyiv: TsIAKR (in Ukrainian).

6. Velychko O. F., Demidov B. O., Naumenko M. V. (2008). Metodychnyi pidkhid do obgruntuvannia dotsilnosti modernizatsii zrazkiv ozbroiennia i viiskovoi tekhniky $v$ ramkakh viiskovo-tekhnichnoho spivrobitnytstva z inozemnymy derzhavamy framework of military-technical cooperation with foreign countries]. Systemy ozbroiennia i viiskova tekhnika, no. 2, PP. 26-29.

7. Behma V. M., Shchehliuk B. P. (2013). Perspektyvy Ukrainy shchodo eksportu tekhnolohii vyrobnytstva tovariv viiskovoho pryznachennia ta podviinoho vykorystannia yak innovatsiinoho napriamu rozvytku vitchyznianoi ekonomiky [Prospects of Ukraine regarding the export of technologies for the production of military goods and dual use as an innovative direction for the development of the domestic economy]. Problemy nauky, no. 12, PP. 21-27.

8. Shymov YU.YU. (2015). Derzhavno-pryvatne partnerstvo $v$ oboronno-promysloviy sferi Ukrayin [Public-private partnership in the defense-industrial sphere of Ukraine]. Stratehichni priorytety, no. 2 (35), PP.20-25. 